J. Lake Sci. (湖泊科学), 2014, 26(2):260-268

http: //www.jlakes.org. E-mail: jlakes@niglas. ac.cn

(c) 2014 by Journal of Lake Sciences

\title{
鄱阳湖典型洲滩湿地土壤含水量和地下水位年内变化特征
}

\author{
许秀 閁 $^{1,2}$, 张 奇 $^{1 * *}$, 李云良 ${ }^{1,2}$, 李相虎 ${ }^{1}$, 王晓龙 ${ }^{1}$ \\ ( 1 : 中国科学院南京地理与湖泊研究所湖泊与环境国家重点实验室,南京 210008) \\ (2: 中国科学院大学,北京 100049)
}

\begin{abstract}
摘 要: 湿地植被空间分布受多个水分因子共同影响,为了探求鄱阳湖典型洲滩湿地不同植被类型下地下水、土壤水的 变化特征, 本文选择鄱阳湖吴城湿地保护区内一个长约 $1.2 \mathrm{~km}$ 的典型洲滩湿地为实验区,建立了气象一土壤一水文联合观 测系统. 对观测的气象、水文要素进行分析发现: (1) 洲滩湿地地下水位年内呈单峰变化, 季节性差异显著, 最大埋深可达 $10 \mathrm{~m}$, 出现在 1 月份, 丰水期 8 月份地下水位最高时可出露地表, 且地下水位与湖泊水位变化具有高度一致性; (2) 由远 湖区高地至近湖区低地, 不同植被带中地下水平均埋深变化为菜蒿带 $(4.76 \mathrm{~m})>$ 芦苇带 $(2.87 \mathrm{~m})>$ 灰化䔔草带

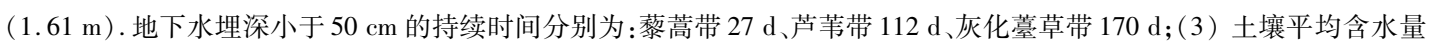
沿不同植被带梯度变化为: 泰蒿带最小 $(15.9 \%)$, 芦苇样带 $(40.7 \%)$ 和灰化菫草样带 $(43.7 \%)$ 较大. 土壤含水量年内变 幅为: 莍蒿带最大 $(2.5 \% \sim 55.2 \%)$, 芦苇带和灰化荎草带相对较小, 分别为 $22.1 \% \sim 48.1 \%$ 和 $28.4 \% \sim 54.1 \%$; (4) 不同 植被带土壤含水量季节变化规律不同, 荺蒿带土壤含水量年内呈单峰型, 仅夏季土壤含水量较高, 其余季节均在 $10 \%$ 左 右,而芦苇带和灰化䔔草样带春、夏、秋季均维持较高含水量 ( $42 \%$ 以上),仅冬季水分含量较低.
\end{abstract}

关键词: 湖泊洲滩湿地;土壤含水量; 地下水位; 现场观测; 鄱阳湖

\section{Inner-annual variation of soil water content and groundwater level in a typical islet wetland of Lake Poyang}

\author{
XU Xiuli ${ }^{1,2}$, ZHANG Qi ${ }^{1}$, LI Yunliang ${ }^{1,2}$, LI Xianghu ${ }^{1}$ \& WANG Xiaolong ${ }^{1}$ \\ (1: State Key Laboratory of Lake Science and Environment, Nanjing Institute of Geography and Limnology, Chinese Academy \\ of Sciences, Nanjing 210008, P. R. China) \\ (2: University of Chinese Academy of Sciences, Beijing 100049, P. R. China)
}

\begin{abstract}
The spatial distribution of wetland vegetation is influenced by a number of hydrological factors, such as groundwater level and soil water content. In order to reveal the characteristics of groundwater level and soil moisture in different vegetation communities, a typical islet wetland of $1.2 \mathrm{~km}$ long in Wucheng National Wetland Reserve was selected as our experiment area. In-situ monitoring system was established to collect data of meteorology, soil and hydrology data of the wetland. Observation data showed that groundwater level was in a significant seasonal variation. The largest groundwater depth was up to $10 \mathrm{~m}$ in January, while the smallest groundwater depth reached the ground surface in August. It was found that the groundwater level was closely correlated with the lake water level, which implied that the islet wetland aquifer could be in a good hydraulic connection with the lake. The groundwater depth was significantly different along the vegetation gradient, with the mean groundwater depths of $4.76,2.87$ and $1.61 \mathrm{~m}$ for Artemisia selengensis, Phragmites and Carex cinerascens communities, respectively. In addition, the numbers of days that the groundwater depth remained for less than $50 \mathrm{~cm}$ was $170 \mathrm{~d}$ for Carex cinerascens, $112 \mathrm{~d}$ for Phragmites and $27 \mathrm{~d}$ for Artemisia selengensis, respectively. The soil water content ranged from $2.5 \%-55.2 \%, 22.1 \%-48.1 \%$, and $28.4 \%-54.1 \%$ for Artemisia selengensis, Phragmites and Carex cinerascens communities, respectively. The seasonal variation of soil moisture for Artemisia selengensis demonstrated a higher value in summer and lower ones in other seasons. While the soil content variation for Phragmites and
\end{abstract}

* 国家重点基础研究发展计划“973”项目 (2012CB417003) 和中国科学院南京地理与湖泊研究所“一三五” 战略发展 重点项目 (NIGLAS2012135001) 联合资助. 2013-02-25 收稿;2013-05-29 收修改稿. 许秀丽 (1987 ), 女, 博士 研究生;E-mail: xlxu1987@163.com.

** 通信作者;E-mail: qzhang@ niglas. ac. cn. 
Carex cinerascens communities was similar, with higher water content in spring, summer, and autumn, and lower in winter.

Keywords: Lake islet wetland; soil water content; groundwater level; in-situ observation; Lake Poyang

湿地植被的生长及分布与土壤含水量、地下水位以及地面水深密切相关 ${ }^{[1-5]}$. 地下水位、积水时间等直 接影响土壤含水量, 继而通过植物生长所需的水分、养分、氧化还原条件等决定植被的组成和分布. 植被与 土壤水分的相互作用与反馈机制维持着湿地生态系统的平衡. 国内外学者已就水文要素与湿地植被开展了 大量工作 ${ }^{[6-12]}$,包括地下水、地表水位的变化, 土壤含水量的波动幅度等. 比如, Castelli 等在 Nevada 的 2 个典 型河流岸滩湿地垂直河岸线布设样带 20 条,利用人工采样和定位自动监测发现,植被的分布与地下水埋深 及其埋深的持续时间密切相关, 不同植被带内地下水埋深、土壤含水量差异显著 ${ }^{[4]}$. Rogel 等在 Mediterranean 的 6 个盐沼湿地的长达 2 年的研究中发现,植被的带状分布主要受土壤最大含水量影响 ${ }^{[9]}$; Bornman 等在南 非 Olifants 人海口的研究也指出, 植被样带的分布取决于地下水埋深和土壤含水量 ${ }^{[10]}$. Dwire 等对位于美国 东北部的 2 个典型的季节性积水草甸湿地进行了 3 个生长季的断面水分定位观测, 湿地年内水位相差近 $60 \mathrm{~cm}$, 汛期地下水可出露地表, 研究认为湿地内 3 个不同的植被群落地下水埋深差异显著, 且物种丰富度、 覆盖度与地下水埋深呈负相关, 总生物量与地下水位平均埋深呈正相关 ${ }^{[11-12]}$. Chui 等通过构建一个地下水 和植被生长竞争耦合模型, 模拟预测了地下水位不同变化情景下植被的生长演替过程 ${ }^{[5]}$. 因此, 研究湿地地 下水位和土壤含水量的变化特征对探讨湿地植被分布有极其重要的作用.

鄱阳湖是受流域来水和长江水位共同作用的淡水湖泊,年内洪枯水位差可达 $12 \mathrm{~m}$, 这种独特的水文节 律变化下形成大面积干湿交替的洲滩湿地,各种不同类型的湿地植物群落根据其对水分因子差异性的响应 沿地面高程梯度呈明显的空间地带性分布 ${ }^{[13]}$, 形成了湿地的生物多样性. 近年来受气候变化和人类活动的 影响, 鄱阳湖干旱事件频发并日趋严重, 水文情势正发生着显著变化 ${ }^{[14-19]}$. 相关研究表明,水文情势的变化 对鄱阳湖湿地植被群落的分布、生物量积累、物种多样性等也造成了不同程度的影响 ${ }^{[20-23]}$. 而目前在鄱阳湖 湿地植被方面也开展了一定的工作,主要集中在湿地植被定性描述 ${ }^{[20-21]}$, 不同水位变化下湿地植被分布面 积的差异 ${ }^{[22-23]}$, 湿地主要物种生长状况的季节变化 ${ }^{[24-26]}$, 湿地不同植被带土壤有机质、营养元素、微生物等 的变化趋势 ${ }^{[26-27]}$. 这些研究对认识鄱阳湖湿地的变化规律奠定了基础. 然而, 针对鄱阳湖典型湿地水文过程 的研究尚不足,仅在短期的样方水分测量 ${ }^{[28-29]}$ 和遥感反演湿地水深、历时等水文要素的统计 ${ }^{[30]}$ 方面有所报 道, 缺乏对湿地植被分布起至关重要作用的土壤水、地下水方面的较为系统和长期的观测与分析, 缺乏对不 同植被类型下水分条件的变化规律的认识.

因此,本文选取鄱阳湖吴城湿地保护区内的一个典型洲滩湿地,详细介绍了气象一水文一土壤多要素联 合观测系统的设计与建立, 并就获取的观测数据进行了分析, 初步揭示了该洲滩湿地土壤含水量和地下水 埋深的变化规律, 分析了洲滩湿地不同植被群落水文过程的差异性, 为今后进一步建立季节性干湿交替湖 泊洲滩湿地生态水文模型奠定了基础.

\section{1 观测系统的设计与建立}

\section{1 观测的科学目标与设计原则}

观测系统的科学目标主要有: (1) 获取干湿交替自然条件下,洲滩湿地土壤水分、地下水位、湖泊水位、 气象要素的同步观测数据,表征湿地水文、气象要素相互作用机制, 为构建湿地水文过程模型提供数据支 撑; (2) 结合植被样方调查和植被生理生态观测, 阐明湿地植被群落分布及其与高程、土壤质地、土壤含水 量、地下水埋深的关系, 为开展湿地生态水文过程模拟研究提供物理基础; (3) 建设成为长期观测实验区, 为鄱阳湖湿地生态水文研究提供典型区实验数据和数学模型.

基于上述目标, 观测系统的设计主要考虑：（1）实验区尺度. 洲滩湿地具有代表性和典型性,观测的尺 度应反映鄱阳湖洲滩湿地植被分布的主要特征和类型; (2) 观测要素. 应全面观测对植被生长有影响的气 象、土壤含水量、地下水位、湖泊水位、土壤质地、地形高程等要素; (3) 观测点的空间布设. 应考虑植被群落 沿高程的变化,观测点位应反映该植被变化梯度所对应的水文要素变化.

\section{2 观测系统的建立}

1.2 .1 实验区的选取 依据系统的观测目标和设计要求, 选择江西省永修县吴城镇以北, 赣江右岸一片近岸 
湿地作为典型样带 $\left(29^{\circ} 24^{\prime} \mathrm{N}, 116^{\circ} 00^{\prime} \mathrm{E}\right)$ 进行观测. 该样带具有以下特点: 为鄱阳湖典型湖泊洲滩湿地, 年内 湖泊水位季节性波动显著, 枯水期洲滩出露, 植被大量发育, 丰水期水位上涨, 湿地有着明显的季节性干湿 交替现象, 能够反映水分的梯度变化; 沿高程和土壤水分梯度植被发育典型, 从远湖区高地至近湖区低洼 地, 分别涵盖了中生性草甸、挺水植被、湿生植被、沉水植被等鄱阳湖洲滩主要植被类型, 且长势良好, 垂直 性分带明显, 适宜进行植被的长期定点观测; 实验区地理位置偏僻, 远离村镇, 避免了放牧、收割、踩踏等人 为因素对植被的干扰, 能够反映自然状态下植被的生长演替.

1.2 .2 实验区概况 实验区地形由陆地向湖区逐渐倾斜,走向与湖水退水方向一致,观测剖面长约 $1.2 \mathrm{~km}$. 最高处毗邻赣江, 河水冲刷严重, 主要呈陡坎台地, 高程为 $18.4 \mathrm{~m}$. 近湖区地势变缓, 最低处与鄱阳湖大湖面 相接, 高程为 $11.2 \mathrm{~m}$, 平均坡度由 $2 \%$ 逐渐过渡为 $0.2 \%$. 洲滩土壤粒径由远湖区向近湖区逐渐变细, 粘粒物 质增多. 发育的植被类型随高程变化呈明显的空间地带性分布, 5 个典型植被样带依次为: 荺蒿( Artemisia selengensis) 样带(本文标识为 I 号)、芦苇(Phragmites) 样带( II 号)、灰化薹草 (Carex cinerascens) 样带 ( III 号)、 曧草 (Phalaris arundinacea) 样带 ( IV 号) 和泥滩(水域) ( V 号), 属于鄱阳湖典型的洲滩湿地植被分布(编号 位置见图 1 ).

1.2 .3 观测要素的选择 自动观测和记录的要素有:气象 (包括温度、湿度、风速、风向、气压、降水和辐射)、 不同深度土壤体积含水量、地下水位、湖泊水位, 观测频次为 $10 \mathrm{~min}$, 数据记录频次为 $1 \mathrm{~h}$. 植被生态指标由人 工定期样方调查和实验室分析获取, 详细信息见表 1 . 土壤含水量传感器在安装结束后, 通过人工浇水方式 对探头周围土体进行恢复, 同时将自动检测数据与便携式水分仪测量结果进行比较和校验.

表 1 鄱阳湖典型洲滩湿地气象、水文、植被监测要素*

Tab. 1 Meteorological, hydrological and vegetation monitoring variables at typical islet wetland of Lake Poyang

\begin{tabular}{|c|c|c|c|c|c|}
\hline 观测内容 & 观测要素 & 传感器型号 & 布设位置 & 记录频率 & 测量精度 \\
\hline 气象 & $\begin{array}{l}\text { 温湿度、风速风向、气压、辐射、 } \\
\text { 降水 }\end{array}$ & DQA130\#C( 降水) & 地面以上 $3 \mathrm{~m}$ & $1 \mathrm{~h}$ & $\begin{array}{c}\text { 降水精度 } \\
\pm 0.2 \mathrm{~mm}\end{array}$ \\
\hline 土壤 & 土壤体积含水量 & MP406 & 地面以下 $10 、 50$ 和 $100 \mathrm{~cm}$ & $1 \mathrm{~h}$ & $\pm 3 \%$ \\
\hline 水位 & 地下水位、湖泊水位 & $\begin{array}{l}\text { DQC001 } \\
\text { 3001Edge LT }\end{array}$ & $\begin{array}{l}\mathrm{I} \sim \text { III 号样带 } \\
\text { II } \sim \mathrm{V} \text { 号样带 }\end{array}$ & $\begin{array}{l}1 \mathrm{~h} \\
1 \mathrm{~h}\end{array}$ & $\begin{array}{l} \pm 0.05 \mathrm{~m} \\
\pm 0.01 \mathrm{~m}\end{array}$ \\
\hline 植被 & $\begin{array}{l}\text { 植物种类、LAI、根系长度、株 } \\
\text { 数、生物量、均高、盖度、茎粗 }\end{array}$ & & I ～IV 号样带,定点样方采样 & 1 个月 & - \\
\hline
\end{tabular}

${ }^{*} \mathrm{I} \sim \mathrm{IV}$ 号样带的具体位置见图 1.

图 1 为观测系统布置示意图. 该系统包括地下水位观测井 3 个 (深度 $8 \sim 12 \mathrm{~m}, \mathrm{G} 1^{\#} \sim \mathrm{G} 3^{\#}$ ) 、土壤水分传 感器 3 组 $\left(\mathrm{S}^{\#} \sim \mathrm{S}^{\#}\right)$ 、湖水位传感器 4 个 $\left(\mathrm{H} 1^{\#} \sim \mathrm{H} 4^{\#}\right)$ 、微气象站 1 套 $(\mathrm{W})$. 地下水位传感器分别于泰蒿、芦 苇、灰化䔔草 3 个典型植被样带内各布设 1 个, 保证湖泊枯水期也监测到地下水位, 用以探求 3 种典型湿地 植被带内地下水动态变化; 土壤水分传感器安装于藜蒿、芦苇、灰化菫草 3 个典型植被样带的不同土壤深 度, 反映植被生长与根系层水分的相互作用过程; 湖泊水位观测传感器分别布设于芦苇带、喜草带、曧草带 及湖区, 能捕获鄱阳湖水位的变幅, 获取洲滩湿地湖泊水位的消涨过程, 推算不同植被带的淹水深度、淹水 频率和淹水历时等水情要素; 微气象站安装于较高地形处. 该系统集数据监测、存储和远程无线传输为一 体. 系统采用太阳能供电和蓄电池备用供电, 实现全自动工作.

\section{2 湿地水文过程分析}

观测数据显示, 2012 年实验区全年降水量为 $1745.6 \mathrm{~mm}$, 季节性分配差异明显, 年内降水主要集中在 3-5 月份, 占全年总量的 $53 \%$. 年平均气温为 $17^{\circ} \mathrm{C}$, 平均湿度 $80 \%$, 最低气温出现在 1 月份, 为 $-5^{\circ} \mathrm{C}$, 最高气温出 现在 7 月份, 为 $36^{\circ} \mathrm{C}$. 地下水位年内波动剧烈, 地下水埋深变化范围为 $0 \sim 10 \mathrm{~m}$, 最低水位出现在 1 月份, 最 高水位出现在 8 月份. 土壤含水量变化范围在 2\% 55\% 之间. 本文在该多要素联合系统建立的基础上, 选取 一周年观测数据,对湿地土壤含水量和地下水位进行分析. 


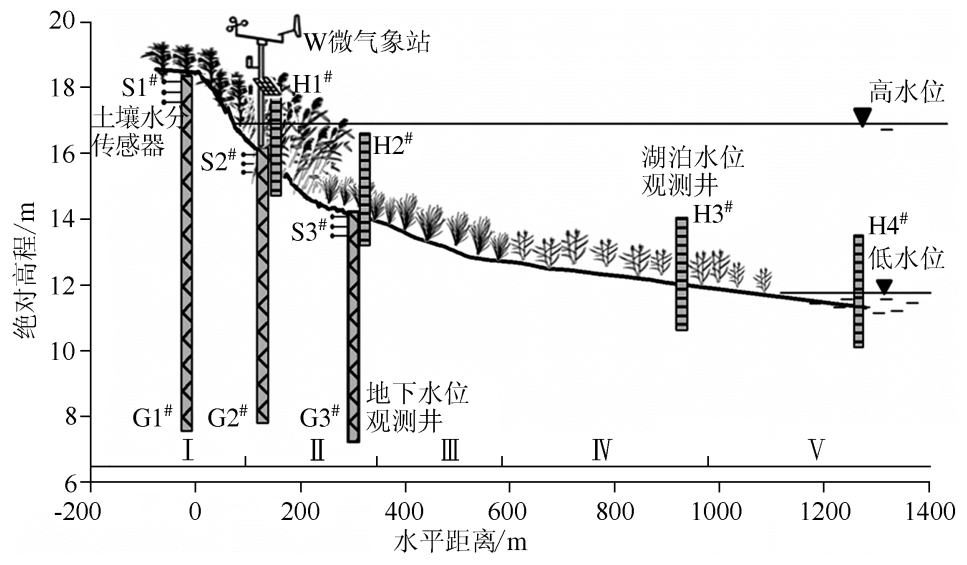

图 1 鄱阳湖典型洲滩湿地气象一水文联合观测系统示意图 ( I V 号分别表示藜蒿、芦苇、灰化薹草、鷊草和泥滩样带)

Fig. 1 Joint monitoring system of meteorology and hydrology at typical islet wetland of Lake Poyang

\section{1 地下水变化及其与降水、湖泊水位的关系}

选取 $\mathrm{G1} 1^{\#}$ 处地下水位观测数据分析地下 水的年内动态特征, 以此作为对鄱阳湖典型 洲滩湿地地下水位变化规律的初步探求. 图 2 显示, 洲滩湿地的地下水位年内呈单峰变 化形式, 有明显的丰、枯变化, 地下水位变幅 可达 $11 \mathrm{~m}$, 水位 (高程) 变化范围为 $8 \sim$ $19 \mathrm{~m}$. 枯水期地下水最大埋深近 $10 \mathrm{~m}$, 出现 在 1 月份, 丰水期最高水位出现在 8 月份, 地 下水位可出露至地表. $1-3$ 月份地下水位较 低,4 月下旬地下水位开始大幅上涨, $5-8$ 月份维持高水位, 平均埋深约 $1.4 \mathrm{~m}, 9$ 月初 地下水位开始逐渐回落, 表现出明显的年周 期性变化.

地下水的年内变化与降水量的季节性 分布有时间上的差异, 地下水位峰值与月降 水量峰值不同步, 地下水峰值出现时间滞后 降水峰值 3 4 个月. 具体来说, 图 2 显示年 内降水主要集中在 3-5 月份, 最大月降雨 量出现在 4 月份, 单月降水占全年降水量的 $24 \%$,而 4 月份地下水的涨幅仅占 $4-8$ 月份 地下水涨幅的 $1 / 3 ; 5$ 月份之后各月降水量大 幅减少并趋于稳定, 7、8 月份降水分别仅占 全年降水的 $3.4 \%$ 和 $4.4 \%$, 而地下水位在该 阶段却是快速上升期, 7、8 月份始终维持高 水位, 峰值出现在 8 月下旬, 地下水溢出

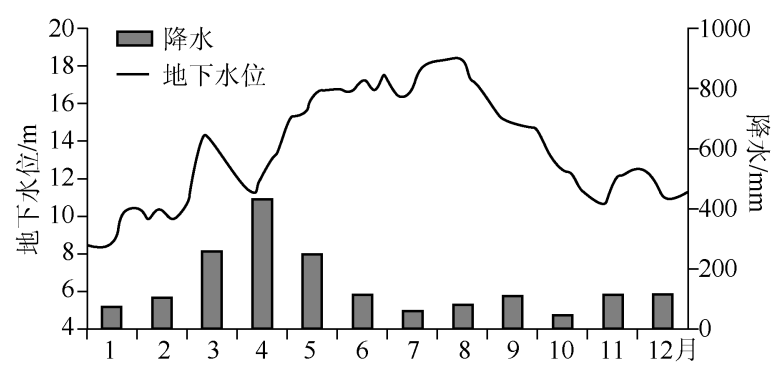

图 22012 年鄱阳湖典型洲滩湿地 $\mathrm{G} 1^{\#}$ 地下水动态变化

Fig. 2 Groundwater level variation of $\mathrm{G} 1^{\#}$ at typical islet wetland of Lake Poyang in 2012

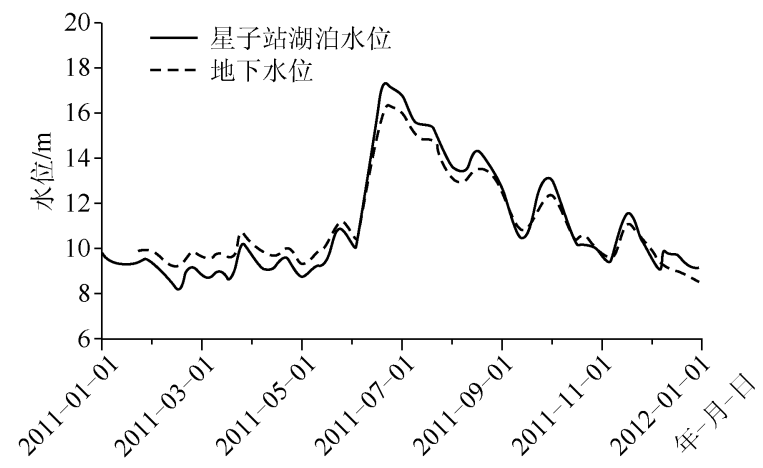

图 3 鄱阳湖典型洲滩湿地地下水位与湖泊水位变化关系

Fig. 3 Correlation of groundwater level and lake water level of typical islet wetland of Lake Poyang 地面.

采用 2011 年 $\mathrm{G} 1^{\#}$ 观测点位地下水与 2011 年星子站湖泊水位数据, 进一步分析地下水与湖泊水位的关 系发现 (图 3), 洲滩湿地地下水位与湖泊水位年内变化过程线形态一致, 出现拐点的时间基本同步, 涨落幅 
度相近, 湖泊水位微小变化都引起地下水位的同步响应, 两者的线性相关系数为 $0.97(P<0.01)$, 表明湖泊 水位是影响该洲滩湿地地下水位变化的直接因子. 实验区为湖滨滩地, 含水层多为砂质, 渗透性极强, 与湖 泊水力联系良好,湖泊水位变化会直接引起地下水位的同步变化.

\section{2 不同植被带地下水位特征分析}

实验区植被沿高程梯度呈典型带状分布, 不同样带的地下水变化差异显著. 依据当地气候水文特征, 将 $3-5$ 月、6-8 月、9-11 月和 $12-2$ 月分别划分为春、夏、秋、冬四季. 2012 年监测数据统计各植被带内地下 水变化如图 $4 \mathrm{a}$.

整体来看, 沿着实验区断面地下水位存在明显的时空差异. 年内各植被带地下水位变化趋势一致, 都有 明显的季节性特征, 表现为冬季地下水埋深最大, 各样带埋深均大于 $4 \mathrm{~m}$, 夏季地下水埋深最浅, 地下水甚至 会出露地表 (地下水埋深 $=0 \mathrm{~m}$ ), 春、秋季居中且春季埋深略小于秋季, 这与鄱阳湖水位变化规律基本一致, 即 6-8 月为汛期, 12-2 月为枯水期. 同时, 不同植被带内地下水埋深差异显著. 高程最高的㴝蒿样带地下 水埋深全年都最大, 年平均埋深 $4.76 \mathrm{~m}$, 变化范围为 $0 \sim 10 \mathrm{~m}$; 芦苇样带次之, 为 $2.87 \mathrm{~m}$, 变化范围为 $0 \sim$ $7 \mathrm{~m}$; 灰化荎草带平均埋深最浅, 仅为 $1.61 \mathrm{~m}$, 变化范围为 $0 \sim 5 \mathrm{~m}$. 嵊蒿样带仅在夏季地下水埋深较浅, 平均 埋深为 $1 \mathrm{~m}$ 左右, 而其余季节地下水埋深均大于 $4 \mathrm{~m}$, 且全年地下水埋深小于 $50 \mathrm{~cm}$ 的时间在 7 月下旬至 8 月中旬, 持续 $27 \mathrm{~d}$; 芦苇样带较藜蒿样带地下水位平均抬升近 $2 \mathrm{~m}$, 春季地下水平均埋深 $2.4 \mathrm{~m}, 6-8$ 月份地 下水即出露地表, 同时芦苇带全年地下水埋深小于 $50 \mathrm{~cm}$ 的天数可持续 $112 \mathrm{~d}$, 出现时间为 5 月 15 日-9 月 3 日; 灰化莒草样带地下水埋深最浅, 平均埋深较芦苇样带又抬高约 $1 \mathrm{~m}$, 春季地下水埋深仅 $1 \mathrm{~m}$, 至夏季地下 水出露地表, 秋季地下水位平均埋深 $1.5 \mathrm{~m}$, 地下水埋深小于 $50 \mathrm{~cm}$ 的时段分别为 3 月初至 3 月下旬和 4 月 下旬至 10 月初, 共可持续 $170 \mathrm{~d}$. 以上分析显示, 不同样带地下水平均埋深由大到小排序为: 藜蒿带 > 芦苇 带 $>$ 灰化荎草带, 埋深小于 $50 \mathrm{~cm}$ 的持续时间为灰化荎草带最大, 藜蒿带的最小 (图 4a). 这种变化特点显然 与植物样带所处的高程有关.

\section{3 不同植被带土壤含水量特征分析}

依据 2012 年植被样带观测数据可知, 3 个植被样带的土壤含水量以莍蒿样带最小, 芦苇样带和灰化菫 草样带较大, 也即距离湖区越近、高程越低, 土壤含水量越高. 著蒿带年内土壤平均含水量仅为 $15.9 \%$, 变化 范围为 $2.5 \%$ 55. $2 \%$, 除夏季土壤含水量大于 $25 \%$ 外, 其余季节均维持在 $10 \%$ 左右; 芦苇样带土壤含水量 整体较高, 平均含水量为 $40.7 \%$, 变化范围为 $22.1 \% \sim 48.1 \%$, 春、夏、秋季土壤含水量基本维持在 $42 \%$ 以 上, 冬季水分含量较低, 在 $32.2 \%$ 左右; 灰化荎草样带土壤含水量与芦苇带差别不大, 年平均含水量为 $43.7 \%$, 变化范围为 $28.4 \% \sim 54.1 \%$, 春、夏、秋季土壤含水量均可达 47\% 左右, 土壤基本呈饱和状态. 此外, 3 个植被样带土壤含水量年内季节性变化规律也有一定的差异. 僽蒿样带平均含水量季节性差异最为显著, 呈现为夏季最高, 冬季最低, 春、秋季居中; 而芦苇带和灰化荎草样带都表现为春、夏、秋 3 季均维持在 $42 \%$ 以上的高含水量, 季节性变化很小 (图 4b). 土壤含水量的季节性变化可能受地形高程、地下水位和土壤质 地的共同影响.

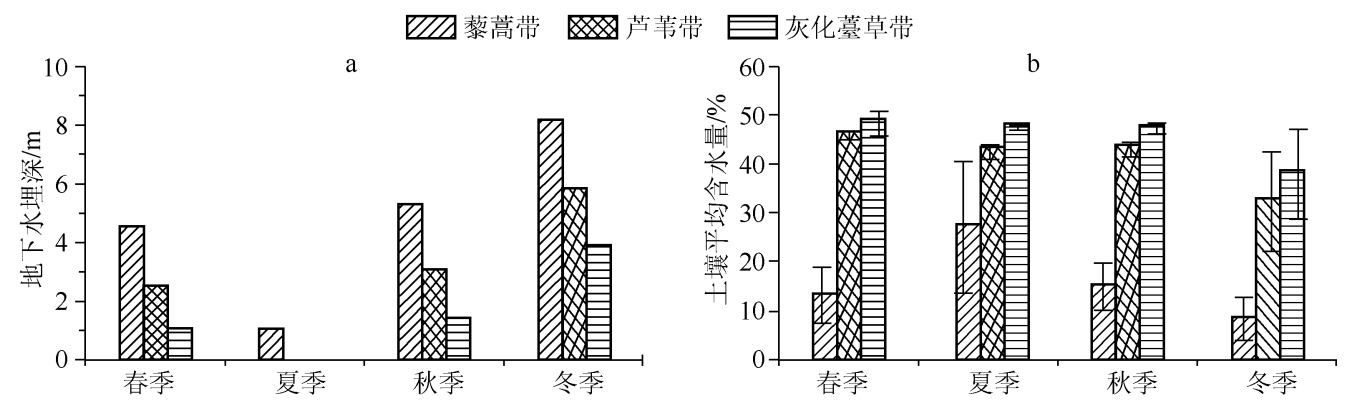

图 42012 年不同植被样带地下水埋深 (a) 和土壤平均含水量 (b) 季节变化

Fig. 4 Seasonal variations of groundwater depths (a) and soil water contents (b)

in different vegetation communities in 2012 
此外, 除了土壤含水量的定点自动观测 外,我们还采用便携式土壤水分仪进行空间加 密的定期人工巡测. 2013 年 1-4 月进行的 4 次沿断面的人工巡测结果与定点自动观测结 果相似 (图 5), 同样显示藜蒿样带土壤含水量 偏低, 而芦苇样带和灰化荎草样带土壤含水量 较高, 维持在 $45 \%$ 左右.

进一步分析各样带土壤含水量沿垂向深 度的变化发现,芦苇样带和灰化䔔草样带不同 深度土壤含水量差异在 $1 \% \sim 4 \%$ 之间, 土壤垂 向水分梯度较小. 而著蒿样带随着土层深度的 增加土壤含水量呈增加趋势 (图 6), 土壤垂向 水分梯度为正, 其中冬季水分梯度小于夏季, 且不同季节剖面土壤含水量大小为夏季 $>$ 秋 季 $>$ 春季 $>$ 冬季. 夏、秋季节表层土壤刚经历 了短期的地下水浅埋对土壤水分的充分补给 过程, 剖面水分含量较大, 且由于不同深度土 壤经历退水的时间先后不同, 下层水分含量显 著高于表层, 增大了土壤的垂向水分梯度, 而 冬季地下水埋深大、降水少, 剖面含水量整体 较小,垂向水分梯度也较小.

\section{4 土壤含水量年内变化过程分析}

选择㢣蒿样带 $\mathrm{S}^{\#}$ 点全年土壤含水量分析 其年内动态变化可知 (图 7), $\mathrm{S1}^{*}$ 点位各层土 壤含水量年内变化趋势基本一致, 表现为先增 大后减小的过程, 季节性变化显著, 同时土壤 含水量年内波动非常剧烈, 最低含水量不足 $10 \%$, 而最高含水量可达 $55 \%$. 此外, 枯水期土 壤含水量整体偏低, 而该阶段地下水深埋对土 壤含水量无显著影响; 丰水期 7-8 月份随着 地下水位的大幅上升,上升毛管水对土壤水 的补给量增大, 土壤含水量迅速增加, 至 8 月 份地下水出露地表时, 土壤层可达到饱和含 水量;之后地下水位下降,土壤层含水量也逐 渐降低至 10\% 左右. 由此可知: 土壤含水量有 明显的季节性周期变化, 其受地下水位的影 响显著.

\section{3 讨论}

\section{1 不同植被带土壤含水量差异的原因}

研究发现, 各样带土壤平均含水量由大 到小排序为: 灰化荎草带 $>$ 芦苇带 $>$ 藜蒿带, 含水量变幅由大到小排序为: 藜蒿带 $>$ 芦苇 带 $>$ 灰化薹草带, 这与已有研究结果基本一

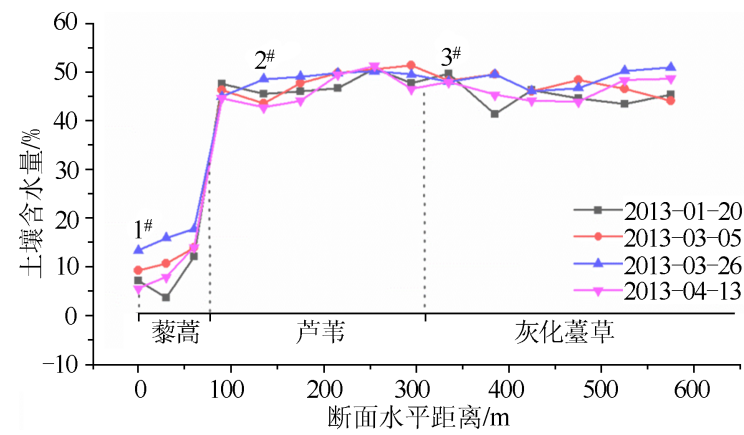

图 52013 年 1-4 月人工巡测土壤含水量沿植物样带 变化 $\left(1^{\#} 、 2^{\#} 、 3^{\#}\right.$ 分别代表 $\mathrm{S}^{\#}$ 、 $\mathrm{S} 2^{\#} 、 \mathrm{~S} 3^{\#} 3$ 组固定土壤 水分观测的安装位置)

Fig. 5 Measured soil water contents for different vegetation communities from January to April, 2013 ( $1^{\#}, 2^{\#}$ and $3^{\#}$ represent the installation position of $\mathrm{S}^{\#}, \mathrm{~S}^{\#}$ and $\mathrm{S}^{\#}$ )

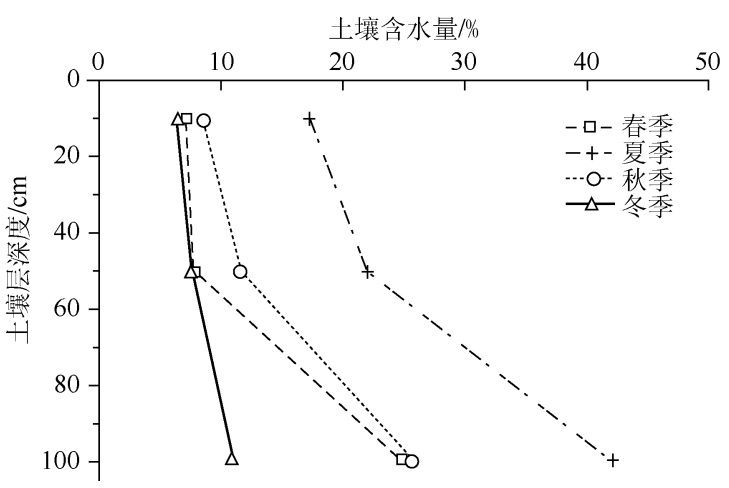

图 62012 年藜蒿样带 $\mathrm{S1}^{\text {\# }}$ 观测点位剖面土壤含 水量的季节变化

Fig. 6 Seasonal variations of soil water contents at different depths of $\mathrm{S}^{\#}$ observation point in Artemisia selengensis community in 2012
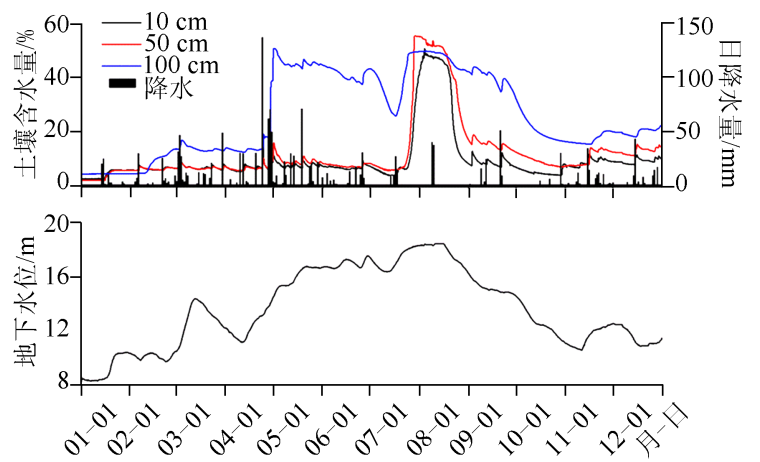

图 72012 年 $S 1^{\#}$ 观测点位土壤含水量年内变化及其 与大气降水量和地下水位的关系

Fig. 7 Annual variation of soil water content of $\mathrm{S}^{\#}$ observation point and its correlation with rainfall and groundwater level in 2012 
致 ${ }^{[20,28]}$. 土壤含水量变化是多种因素共同作用的结果, 包括水分输人、储存、输出的动态平衡 ${ }^{[34]}$. 实验区不 同植被样带土壤含水量空间变化的原因主要有以下两个方面:第一为不同植被带所处高程不同. 实验区著橧 蒿带处于 $18 \mathrm{~m}$ 高程, 芦苇和灰化䔔草带分别位于 16 和 $13 \mathrm{~m}$ 高程处, 地形高程差异使得年淹水时长为灰化 荎草带 $>$ 芦苇带 $>$ 莍蒿带. 观测数据还显示, 地下水位平均埋深为藜蒿带 $>$ 芦苇带 $>$ 灰化荎草带, 埋深小于 $50 \mathrm{~cm}$ 的持续时间为灰化荎草带 $>$ 芦苇带 $>$ 著蒿带, 当地下水埋深较浅时, 土壤可以得到上升毛管水的补给 而维持较高的土壤含水量, 随着地下水埋深变深, 土壤得到的水分补给减少, 因此, 著蒿带土壤水受湖水和 地下水的补给远小于芦苇带和灰化䔔草带, 导致了藜蒿带土壤含水量在植物样带中最小; 第二, 不同样带土 壤属性不同, 储水性能差异大. 本文的土壤剖面野外调查发现, 莍蒿带土壤主要为砂质, 而芦苇带和灰化菫 草带土壤中淤泥质成分增多, 土壤粒径变细, 这与已有研究结果是一致的. 比如, 董延钰等对鄱阳湖大汉湖 沉积物粒度分析发现, 从湖滨至湖心沉积物粒度由粗砂-细砂-粉砂-黏土等逐渐变细 ${ }^{[31]}$; 胡春华等对鄱阳湖 不同沉积断面的采样分析也发现, 由草滩顶部-草滩中部-草滩底部, 随着高程的降低沉积物中砂含量逐渐 降低, 泥质含量逐渐增加 ${ }^{[32]}$. 显然粘粒成分的增多有利于水分的保持 ${ }^{[33]}$. 因此, 愁蒿样带较芦苇和灰化菫草 样带土壤渗透性更强, 持水性能差, 降水、地下水补给后土壤水分难以保持, 水分平均含量偏低且波动幅 度大.

\section{2 各植被带地下水、土壤水、积水深度与植被生长习性的关系}

植被生长的各个阶段都与土壤水分条件密切相关, 萌发期土壤水分含量的大小可直接影响物种的萌发 率, 同时生长期水分含量的大小会决定幼苗的存活、长势等 ${ }^{[34-35]}$. 本研究发现, 莍蒿样带处于实验区地形最 高处, 高程 $18 \mathrm{~m}$ 左右, 年淹水时间最短, 地下水埋深大, 土壤含水量极低, 这种水分严重匮乏的生境条件显 然不适宜挺水和湿生植被的长期生存, 这在一定程度上决定了研究区芦苇和灰化䓵草分布的上限, 同时一 些水分需求量小且不耐水淹的中生性草甸植物在长期的生态适应过程中逐渐成为该类生境下的优势种.

芦苇样带位于 $14 \sim 16 \mathrm{~m}$ 高程之间, 每年 3 月底开始萌发, 4-5 月为幼苗发育期, 且幼苗期需水量不大, 不适宜长期淹水. 本研究结果显示 $16 \mathrm{~m}$ 高程 3-5 月份土壤含水量为 $45 \%, 5$ 月份平均地下水埋深为 $32 \mathrm{~cm}$, 由此形成的地表湿润环境非常适宜芦苇的萌发生长 ${ }^{[22]}$. 同时 6-8 月份地下水溢出地表, 地面平均积水深度 在 $1 \sim 2 \mathrm{~m}$ 之间, 芦苇带部分淹水. 6-9 月份是挺水植物的关键生长时期, 该阶段的部分淹水可促进芦苇的 快速生长 ${ }^{[20]}$, 而完全淹水则不利其生长, 因此 $14 \mathrm{~m}$ 高程以下区域其 6-8 月过高的积水深度在一定程度上 可能限制了芦苇分布的下限.

灰化荎草是鄱阳湖湿地分布范围最广的湿生植被, 一年有 2 个生长周期, 分为春季荎草和秋季荎草. 春 草每年 2 月萌发, 3-4 月快速生长 ${ }^{[13]}$, 此阶段地下水平均埋深约 $1 \mathrm{~m}$, 土壤含水量可达 $48 \%$, 能保证春季灰 化荎草的生长需水. 5 月初地下水出露地表, 菫草第 1 个生长期在淹水前已基本完成, $6-8$ 月份菫草带被全 部淹没, 洜草因长期水淹而逐渐枯死或休眠. 至 9-11 月份鄱阳湖退水, 为萄草的秋季萌发生长期, 此时土 壤含水量可达 $47 \%$, 地下水位平均埋深 $1.5 \mathrm{~m}$, 为秋季荎草的萌发提供了充足的水分供给. 荎草的这种生长 规律是对鄱阳湖特定水情变化下的一种生态适应 ${ }^{[13]}$.

\section{4 结论}

1) 鄱阳湖典型洲滩湿地地下水位有明显的季节性变化特征, 枯水期地下水最大埋深近 $10 \mathrm{~m}$, 出现在 1 月份, 丰水期最高水位出现在 8 月份, 地下水可出露至地表. 且地下水位动态变化与湖水位变化具有高度一 致性,显示了该洲滩湿地地下含水层与湖泊良好的水力联系.

2) 不同植被带地下水位表现出一致的季节性变化和差异显著的空间变化. 3 个植被带年内地下水位变 化规律都为冬季埋深最大, 夏季埋深最小, 春、秋季居中. 不同植被带地下水埋深由大到小为: 蔡蒿带 $(4.76 \mathrm{~m})>$ 芦苇带 $(2.87 \mathrm{~m})>$ 灰化荎草带 $(1.61 \mathrm{~m})$, 地下水埋深小于 $50 \mathrm{~cm}$ 的持续天数由大到小为: 灰化 薹草带 $(170 \mathrm{~d})>$ 芦苇带 $(112 \mathrm{~d})>$ 藜蒿带 $(27 \mathrm{~d})$.

3 ) 不同植被带土壤含水量以藜蒿带最小 ( $15.9 \%)$, 灰化菫草样带最大 ( $43.7 \%$ ), 芦苇样带居中 $(40.7 \%)$. 僽蒿带土壤含水量变幅最大 $(2.5 \% \sim 55.2 \%)$, 芦苇带和灰化荎草带较小. 不同植被带土壤含水 量季节变化规律不同, 葱蒿带土壤含水量年内呈单峰变化形式, 仅夏季土壤含水量较高, 而芦苇带和灰化菫 
草样带春、夏和秋季土壤都维持高水分含量,仅冬季较低. 不同植被带土壤垂向水分梯度不同,藜蒿带土壤 水分梯度明显, 而芦苇带和灰化荎草带土壤水分垂向梯度不明显. 实验区土壤水分受地下水埋深影响显著. 致谢: 感谢江西省三江湖办公室夏雨提供星子站 2011 年湖水位观测数据.

\section{5 参考文献}

[1] 刘 永,郭怀成,周 丰等. 湖泊水位变动对水生植被的影响机理及其调控方法. 生态学报, 2006, 26(9): 3117-3126.

[ 2 ] Runhaar H, Witte F, Verburg P. Groundwater level, moisture supply, and vegetation in the Netherlands. Wetlands, $1997,17(4)$ : 528-538.

[ 3 ] Hupet F, Vanclooster M. Intraseasonal dynamics of soil moisture variability within a small agricultural maize cropped field. Journal of Hydrology, 2002, 261 (1/2/3/4): 86-101.

[ 4 ] Castelli RM, Chambers JC, Tausch RJ. Soil-plant relations along a soil-water gradient in Great basin riparian meadows. Wetlands, 2000, 20(2): 251-266.

[ 5 ] Chui TFM, Low SY, Liong SY. An ecohydrological model for studying groundwater-vegetation interactions in wetlands. Journal of Hydrology, 2011, 409(1/2) : 291-304.

[6] 崔保山, 赵欣胜, 杨志峰等. 黄河三角洲芦苇种群特征对水深环境梯度的响应. 生态学报, 2006, 26 (5): 1533-1541.

[ 7 ] 陈亚宁,李卫红, 徐海量等. 塔里木河下游地下水位对植被的影响. 地理学报,2003, 58(4): 23-27.

[8] 谭学界,赵欣胜. 水深梯度下湿地植被空间分布与生态适应.生态学杂志,2006, 25(12): 1460-1464.

[ 9 ] Rogel JA, Ariza FA, Silla RO. Soil salinity and moisture gradients and plant zonation in Mediterranean salt marshes of Southeast Spain. Wetlands, 2000, 20(2) : 357-372.

[10] Bornman TG, Adams JB, Bate GC. Environmental factors controlling the vegetation zonation patterns and distribution of vegetation types in the Olifants Estuary, South Africa. South African Journal of Botany, 2008,74(4):685-695.

[11] Dwire KA, Kauffman JB, Baham JE. Plant species distribution in relation to water-table depth and soil redox potential in montane riparian meadows. Wetlands, 2006, 26(1) : 131-146.

[12] Dwire KA, Kauffman JB, Brookshire ENJ et al. Plant biomass and species composition along an environmental gradient in montane riparian meadows. Oecologia, 2004, 139(2) : 309-317.

[13] 刘信中, 叶居新. 江西湿地. 北京: 中国林业出版社, $2000: 203$.

[14] 叶许春,张 奇,刘 健等. 气候变化和人类活动对鄱阳湖流域径流变化的影响研究. 冰川冻土, 2009,31 (5): 835-842.

[15] 闵 骞,闵 聑. 鄱阳湖区干旱演变特征与水文防旱对策. 水文,2010,30(1):84-88.

[16] 闵 骞,占腊生. 1952-2011 年鄱阳湖枯水变化分析. 湖泊科学,2012,24(5):675-678.

[17］郭 华,张 奇. 近 50 年来长江与鄱阳湖水文相互作用的变化. 地理科学,2011, 66 (5) : 609-618.

[18］甘小艳,刘成林,黄小敏. 鄱阳湖干旱分析. 安徽农业科学,2011,39(24): 14676-14678.

[19] Zhang Q, Li L, Wang YG et al. Has the Three-Gorges Dam made the Poyang Lake wetlands wetter and drier. Geophysical Research Letters, 2012, 39(20). doi :10. 1029/2012GL053431.

[20] 胡振鹏, 葛 刚,刘成林等. 鄱阳湖湿地植物生态系统结构及湖水位对其影响研究. 长江流域资源与环境, 2010, $19(6)$ : $597-605$.

[21] 吴建东,刘观华,金杰峰等. 鄱阳湖秋季洲滩植物种类结构分析. 江西科学, $2010,28(4): 549-554$.

[22] 余 莉,何隆华,张 奇等. 三峡工程蓄水运行对鄱阳湖典型湿地植被的影响. 地理研究,2011, 30(1): 134-144.

[23] 余 莉,何隆华,张 奇等. 基于 Landsat-TM 影像的鄱阳湖典型湿地动态变化研究. 遥感信息, 2010, 6: 48-54.

[24] 吴 琴, 尧 波,朱丽丽等. 鄱阳湖典型苔草湿地生物量季节变化及固碳功能评价. 长江流域资源与环境,2012, 21 (2) : 215-219.

[25] 于旭光, 鲁顺保, 江玉梅等. 鄱阳湖南矶山湿地灰化苔草季节生长动态研究. 井冈山大学学报, 2010,31 (5): 129-132.

[26] 张全军,于秀波,钱建金等. 鄱阳湖南矶湿地优势植物群落及土壤有机质和营养元素分布特征. 生态学报,2012, 32 (12) : 3656-3666. 
[27] 王晓龙,徐立刚,姚 金等. 鄱阳湖典型湿地植物群落土壤微生物量特征. 生态学报,2010,30(18): 5033-5042.

[28] 吴 琴, 尧 波, 幸瑞新等. 鄱阳湖典型湿地土壤有机碳分布及影响因子. 生态学杂志, 2012, 31(2): 313-318.

[29] 䓪 刚,赵安娜, 钟义勇等. 鄱阳湖洲滩优势植物种群的分布格局. 湿地科学, 2011, 9(1): 19-25.

[30 ] Zhang LL, Yin JX, Jiang YZ et al. Relationship between the hydrological conditions and the distribution of vegetation communities within the Poyang Lake National Nature Reserve, China. Ecological Informatics, 2012,11:65-75.

[31] 董延钰, 金 芳, 黄俊华. 鄱阳湖沉积物粒度特征及其对形成演变过程的示踪意义. 地质科技情报, 2011, 30(2): $57-62$.

[32] 胡春华, 朱海虹. 鄱阳湖典型湿地沉积物粒度分布及其动力解释. 湖泊科学, 1995, 7 (1) : 21-32.

[33] 邵明安,王全九,黄明斌. 土壤物理学. 北京: 高等教育出版社,2006: 22-23.

[34] Moore DRJ, Keddy PA. Effects of a water-depth gradient on the germination of lakeshore plants. Canadian Journal of Botany, 1988, 66(3) : 548-552.

[35] Fay PA, Schultz MJ. Germination, survival, and growth of grass and forb seedlings: effects of soil moisture variability. Acta Oecologica, 2009, 35(5): 679-684. 